Stete of Alaska

Department of Natural Resources DIVISION OF MINES AND MTNERALS

\section{PROPERTY OF LIBRARY \\ STATE OF ALASKA DIVISION OF GEOLOGICAL SURVEY}

MTNES BULLETIN

January, 1961
P. 0. Box 1391

Juneau, Alaska

Vol. IX

No. 1

\title{
MUNING ACTIVITIES
}

FIRST DISTRICT - Admiralty Alaske Gold Mining Company is continuing their diamond drill exploration program from the 200 level at Funter Bay.

\section{MORE MINING REGULATIONY YEARINGS}

As reported in lest month's Bulletin, some rather broad departures from conventional mining law are contemplated for regulating mining activities on lands that will be owned by the state. Since no advance time was available before the November hearings durlng which the changes Irom our earlier distributed regulations could be considered, it has been deemed advisable to hold a second round of hearings. The redraft of the proposed regulations should be ready for distribution about January 12. It will be sent to all who attended the first hearings and also to those who requested tbe original proposed regulations. Others may obtain it from this Division at Box 1391, Juneau or the Division of Lands at 344 Sixtb Street, Anchorage. The second round of public hearings will not be as extensive as the first. They are planned for Anchorage on February 7 , at Fairbanks on February 8, and Juneau on February 10. We continue to emphasize that these proposed new regulations will not affect claims now in existence nor clajms staked in the future on Federal Public Domain.

\section{OD NEWS}

According to Mr. P. W. Gester, geologist for the standard oil Company, "the volume of oll exploration activity in 1961 will increase by 25 percent in total drilling over 1960. This might be added up into a general prediction that the oil induatry rate of expenditure for 1961 Nill be in the range of $\$ 40,000,000$ to $\$ 50,000,000 . "$

During the montb of December this Division approved applications for permit to drill wells Nos. Solóotna Creek Untt $32-8$ and 43-33, Standard 011 Company of California, operator. As of the 27 th of December, a total of 30 applications have been approved, representing an increase of 87.4 percent over 1959.

Since the November bulletin, Standard 01l Co. of California, Operator has announced the completion of three additional wells in the Soldotna Creek Un1t. On November 26, 1960, well No. SCU 34-4, was completed flowing at a calculated MER of 800 barrels per day of 37.7-degree gravity 011. On December 27, 1960, stendard announced that both wells Nos. SCU $14-34$ and $14-9$ had beel completed, flowing at a calculated MER of 700 barrels per day ea,ch. Oil producers in the Swanson River Oil Field now totel 18.

In accordance with Section 2008.1, Title 11 AAC (011 \& Gas Conservation Regulations) records covering the drijiing of well No. Swanson River Unit 22-23 are now released to the public.

BE SURE TO SFIND IN YOUR "PINK SLIP" -- PAGE ? 

On December 7 th the Division of Lands held the State's thira competitive o1I and gas lease sale in Anchorage at which there were 9 tracts bio on covering 22,867 acres out of 26 offered covering 73,048 acres. El Paso Natural Gas Products Company submitted bids totaling \$19,52l.25 on five tracts located in Herendeen Bay covering 15,758 acres for an average of $\$ 1.23 /$ acre. Union 01l Co. of Californis and Ohio Oil Co. jointly submitted one bid on an 1852 acre tract of sshore the Kenai Gas Unit totaling $\$ 10,026.25$ for an everage of $\$ 5.41$ /acre. Richfield Oil Corp. bid $\$ 5,777.81$ covering 5,257 acres offshore Katalla for an average per acre bid of \$1.09. The nine tracts brought a total of $\$ 35,325.31$ for an average or $\$ 1.54 /$ acre.

\section{Current Drilling Activity as of December 27,1960}

$\begin{array}{ll}\text { Operator } & \text { Well No. } \\ \text { Richfield } & \text { Kaliakh River Unit aRD } \\ \text { SOCal } & \text { Falls Creek 1 } \\ \text { SOCal } & \text { SCU } 32-9 \\ \text { SOCal } & \text { SCU } 32-8 \\ \text { SOCal } & \text { SCU } 43-33 \\ \text { SOCal } & \text { SRU 23-27 } \\ \text { Union } & \text { Kenai Unit 41-19 }\end{array}$

Status

Drilling @ $10,374^{\prime}$
Drilling @ $5,436^{\prime}$
Drliling @ $8,367^{\prime}$
Moving on location
Moving on location
Drilling @ $8,317^{\circ}$
Running surface casing
Present T. D. 1,188'.

\section{WITHMRAWAIS}

Just after we quoted an undersecretary as saying that Secretary Seaton probably would not withdraw the Arctic National Wildilfe Range last month, he did it. There seems to be some confusion resulting from varlous news releases as to whether or not mining will be allowed in the withdrawn Range. Under the regulations as published in the Federal Register (Fublic Land Order 2214), it will not. We quote the pertinent paragraph from the order as follows:

\footnotetext{
"For the purpose of preserving unique wlldlife, wllderness and recreational values, all of the hereinafter described area in northeastem Alaska, containing approximately $8,900,000$ acres is hereby, subject to valid existing righta, and the provisions of any existing withdrawals, withorawn from all forms of approprlation under the public land laws, including the mining but.not the mineral leasing laws, nor disposals of materials under the Act of July 31, 1947 (61 stat. 681; 30 U.S.C. 601-604), as amended, and reserved for use of the United States Fish and Wlalife Service as the Arctic National Wilalife Range."
}

From this we see that mineral leasing laws (oil, gas, coal, etc.) wlll apply, but mining law (metals and other locatable minerals) will not. In a public release, Senator Bartlett addressed the following remarks to a newspaper editor:

\footnotetext{
"Further, your implication that the Secretary of the Interior wes forced to create the range with an sbsolute prohibition against mineral exploration and mining is totaliy erroneous. There are five extsting wildlife ranges in the United Statea, excluding the Kenai Moose Range, which was especially created to carry out the provisions of the territorial game low. In each of these, mining location is allowed. In none do limitations exiat such as those which were proposed in the leglslation offered by the Secretary of the Interior."
} 


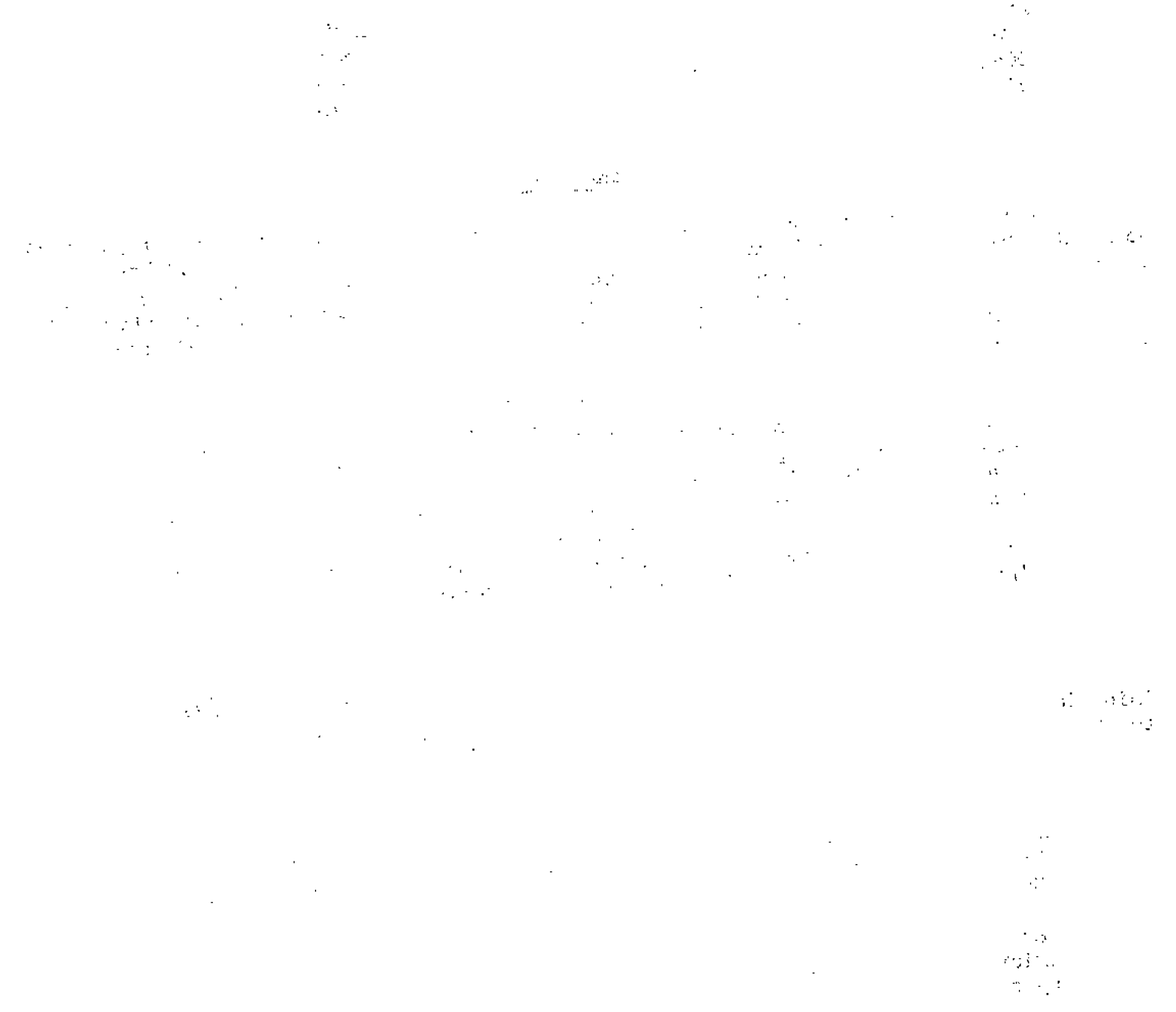


Simultaneously with the above action, the Secretary withdrew the Kuskokwim National Wildlife Range (approximately 1,870,000 acres), the Izembek National Wilalife Range (approxinately 320,000 acres) and opened to nonmineral public land laws the approximately $20,000,000$ acres on the Arctic Slope that were opened to mineral entry under both mining and mineral leasing laws in 1958. The 24,000,000-acre Naval Petroleum Reserve No. 4 remains closed.

\section{TIN}

World production of tin is not keeping pace with consumption and the International Tin Council's removal of output quotas will not produce sufficlent tonnage to close this gap. Consumption of tin in 1960 is estimated at 170,000 tons with world production and release of stocks totaling only 158,000 tons, 12,000 tons below consumption.

The squeeze has not fully developed as yet due to heavy de-stocking being carried on by febricators, particularly in the U.S. But once the U. S. economy picks up and consumers are forced back into the market, it is felt the shortage will become obvious. The International Tin Councll has a buffer stock of 10,000 tons of tin; sales from this buffer stock can only be made when the price reaches $\$ 2324.00$ a ton or $\$ 1.16$ a pound. If the anticipated shortage forces prices beyond that point, the stock manager would have to take action to prevent a runaway market. How far. could the buffer stock be safely depleted?

The U. S. agreed to lead Bolivia $\$ 10$ million in November to improve and modernize the ore concentration facilities of Bolivia's tin mines. This loan will help Bolivia's nationalized mine corporation, :Comibel, to reduce shipping costs and increase production by processing low grade concentrates.

\section{GEOLOGIC REPORTS}

The Geological Survey is releasing in open files - "The Geologic Interpretation of Magnetic Deta in the Copper River Basin, Alaska," by G. E. Andreasen, Arthur Granty, and Isidore Zletz - at Brooks Memorial Building, College; 117 Capital Bullding and in State Division of.Mines and Minerals, Room 317, Alaske Office Bldg., Juneau; and 503 Cordova Bldg., Anchorage, Alaska. Coples for which reproduction of text and illustrations can be made at private expense are available at Alaskan Branch, U. S. Geological Survey, 345 Middlefield Road, Menlo Park, California.

\section{GOLD}

Gold is enjoying increasing use in the plating of vital electronic and missile parts, sucb as brackets for space satellites, sealing rings for rissiles, electronic chassis and electronic houshngs. It is reported that as much as $\$ 50$ per oz. is being paid for the cyanide powder gold which is used in this special plating process.

Because of their indirect effect on the balance-of-payments problem, domestic prices of gold and silver are not likely to be raised by the new administration, despite some pressures along those lines from the mining bloc in Congress and even within the administration itself. However, subsidies of one form or another are a good bet to be proposed in the new Congress.

HAPPY NEW YEAR! 


\section{ETCETERA}

Adaition of from 10 to 20 percent of ordinery 'salt to "permissible" explosives used in the coal mines increased their safety factor according to a report just pubilshed by the U. S. Bureau of Mines, Report of Investigation 5683, "Reducins Incendivity of. Permissible Explosives by Sodium Chloride," which may be obtained from the Publications Distribution Section, U. S. Bureau of Mines, 4800 Forbes Ave., Pittsburgh 13, Pennsylvania. The addition of salt to "permissible" explosives in varying proportions cools the flame emitted by explosives thus lessentng their chance of igniting gas or coel dust.

E. AND M. J. METAL MARKET PRICES

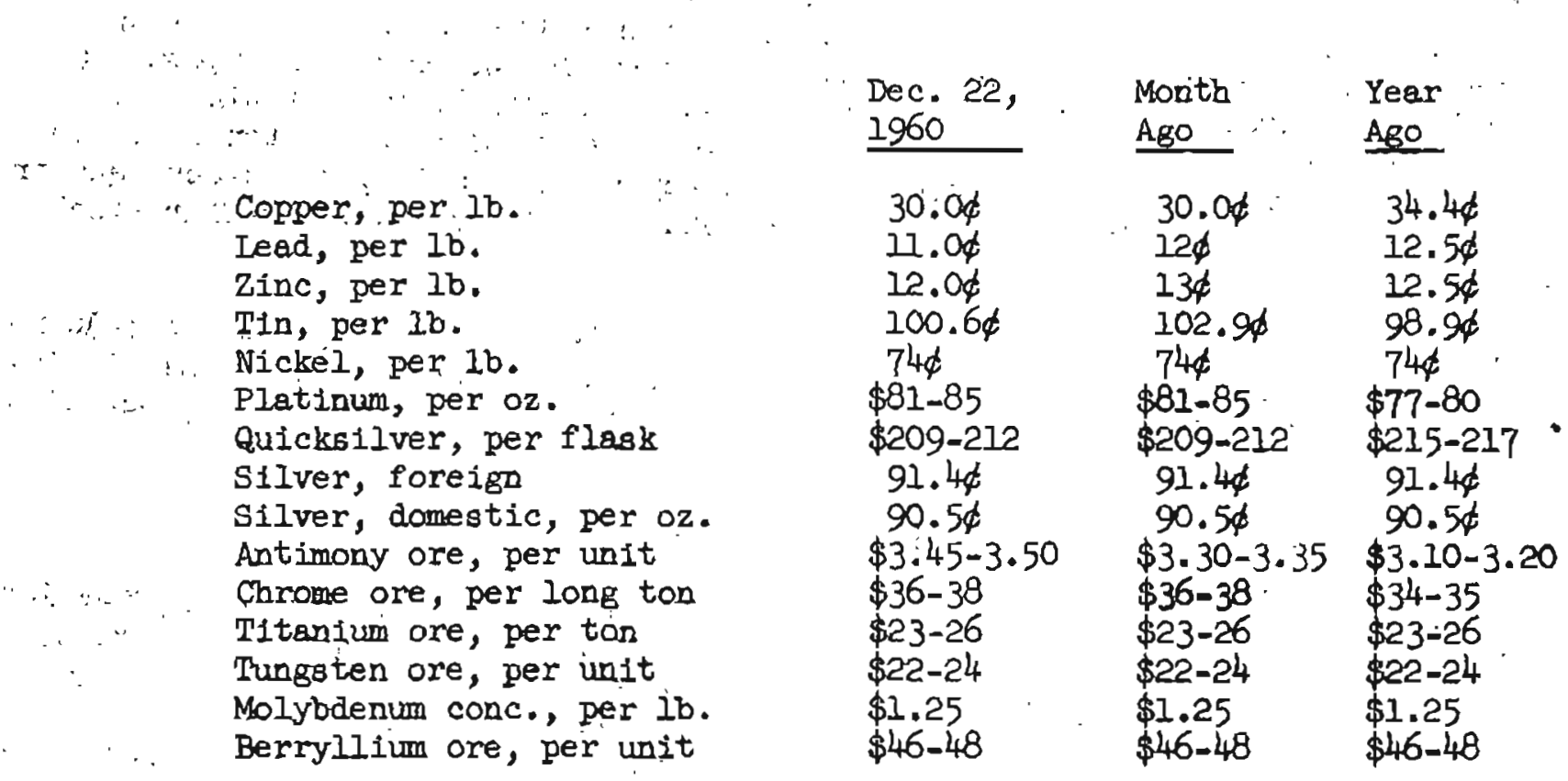

IF YOU WISH TO CONTINUE RECEIVING THTS BULLETIN,

BE SURE TO SEND IN YOUR "PINK SLIP" -. PAGE 2. 